\title{
Ludwig Hamburger (1890-1968): from relaxation oscillations to business cycles
}

\author{
Franck Jovanovic, TELUQ University, Canada, and LEO, Université \\ d'Orléans, France
}

To be published in History of Economics Review in 2021.

\begin{abstract}
Several authors have been interested in Ludwig Hamburger's attempt to analyze business cycles with a nonlinear endogenous model in the early 1930s. Indeed, Hamburger was one of the first, if not the first, to suggest applying Van der Pol's relaxation oscillations to business cycles. Ragnar Frisch was interested in his work when he was working on his 1933 seminal paper on propagation-impulse model, in which we find some references to this suggestion. Despite the interest in Hamburger's work, the breadth, scope, and impact of his works remain unknown and misunderstood, for both historians of economics and sciences. Moreover, several errors, such as the reason why Hamburger did not continue his original work in economics, exist in the economic literature concerning this author and the diffusion of his work in economics. The present work provides the biography of Ludwig Hamburger and corrects the errors we find in the literature. It also sheds new light on the origins of his attempt to analyze business cycles with a nonlinear endogenous model.
\end{abstract}

Keywords: Ludwig Hamburger; Lodewijk Hamburger; Lawrence Harbury; Ragnar Frisch; Philippe Le Corbeiller; history of business cycles; relaxation oscillations

Contact: Franck Jovanovic, franck.jovanovic@teluq.ca 


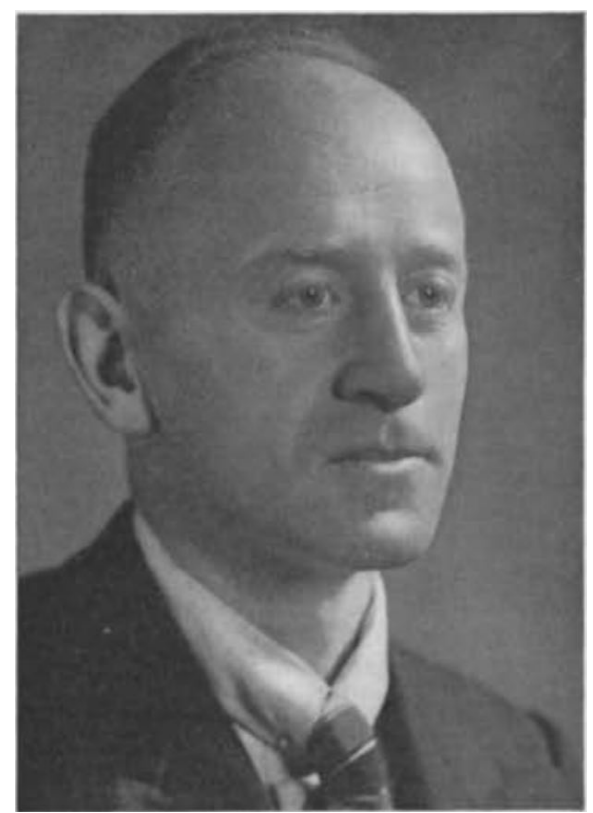

Source: Brugmans and Japikse (1938, p. 596).

Several authors have been interested in Ludwig Hamburger's attempt to analyze business cycles with a nonlinear endogenous model in the 1930s (Assous and Carret 2021; Ginoux 2017; Le Gall 1994; Rosser 2016; Venkatachalam and Velupillai 2012). ${ }^{1}$ Nevertheless, the breadth, scope and impact of his work has not been deeply analyzed by either historians of economics or sciences. This article biography aims at presenting Hamburger's life, his work in economics and where his idea to analyze business cycles with a nonlinear endogenous model came from.

Ludwig (or Lodewijk) Hamburger (1890-1968) was born in Amsterdam (The Netherlands) on 12 December 1890. He was the son of Alexander Hamburger (1858-1943) and Bertha Cosmann (1860-?), and married Josephine Elion (1897-1971) on 23 September 1924 ('s-Gravenhage, The Netherlands). ${ }^{2}$ Ludwig died in California (USA) on 7 January 1968. Contrary to the claim of Venkatachalam and Velupillai (2012, p. 59) ("Hamburger's imaginative and original line of economic research was sadly terminated by the tragedy of the holocaust"), the reason why Hamburger did not continue his original work in economics has nothing to do with his death. In fact, he was a chemical engineer and entrepreneur. Despite his interest in economic crises and price fluctuations, he was neither an economist nor an academic. His original work in economics appears like an interlude in his career.

\footnotetext{
${ }^{1}$ The present work is an extended version of the elements presented in a first version of a working paper with Jean-Marc Ginoux on "The "rocking horse model does rock": solving Zambelli's puzzle". We shared this working paper with Vincent Carret on 16 October 2020. On 29 April 2021, Michaël Assous and Vincent Carret sent me their working paper on "Relaxation oscillations in the early development of econometrics: coming (almost) full circle (1929-1951)".

${ }^{2}$ Source: https://www.openarch.nl/hga:D9DD4D96-8139-46C0-94E9-6DC14D0D4F49/fr.
} 
In 1912, Hamburger graduated as a chemistry engineer. From that date he joined the Koninklijk Instituut Van Ingenieurs (Royal Institute of Engineers) which is the professional association of engineers in the Netherlands. This association has its own publication, De Ingenieur, in which Hamburger published his first articles in economics. Hamburger was an active member of this association until he left the Netherlands in 1939. On 11 February 1913, Hamburger joined the Philips' Light Bulb Factories (The Netherlands) and worked as chemical engineer at Philips' Chemical Laboratory. ${ }^{3}$ The first publications of the Register van de Laboratoria der N.V. Philips Gloeilampenfabrieken (Register of the laboratories of the N.V. Gloeilampenfabrieken) was on his name, one together with Ir. D. Lely, two together with Drs. Filippo and two together with Dr. G. Holst. On July 4, 1917, while he was working at Philips, Ludwig defended his doctorate thesis in technical sciences at the Technische Hogeschool (Technical College) in Delft in front of his two supervisors, Willem Reinders (1874-1951) and Lodewijk Hendrik Siertsema (1863-1945). His thesis was in physical chemistry and chemical engineering on "Concerning light emission of gases and mixted gases upon electrical discharges" ("Over licht-emissie door gassen en mengsels van gassen bij electrische ontladingen"). ${ }^{4}$ Then, on 11 June 1917, he left Philips and founded and took the leadership of the Syndicate for the preparation of chemical products in Schiedam (Brugmans and Japikse 1938, p. 596) in order to produce nitrogen and Ammonia for the Dutch government during the First World War. ${ }^{5}$ On the basis of the results obtained with this Syndicate, Hamburger founded the $N$. $V$. Stikstofbindingsindustrie (N. V. Nitrogen bonding industry) the same year, and became its director. The same year, he was also ranked number one by the Department of Chemical Technology at Delft University of Technology to fill a vacancy in the Chair of Chemical Technology. However, Hamburger did not have enough experience to fill the position (Brugmans and Japikse 1938, p. 596). In 1924, the Royal Institute of Engineers inaugurated its Section for Technical Economics. Hamburger joined the new section. On this occasion, he expressed some of his views on economics. He claimed that we should speak of "sociology" instead of "economics" (De Ingenieur 1924, n. 23, page 2).

Between 1925 and 1932, Ludwig devoted himself mainly to scientific research. During these seven years, he published several academic articles and books in chemistry and physics, and also in economics (see the list below for his publications in economics). We can observe two periods in his research in economics. He started by analyzing price volatility. Hamburger developed an elaborate attempt to analyze mathematically the theory of purchasing power parity (the modern formulation of this theory was proposed by Gustav Cassel in 1916). One of his conclusions was to claim that the purchasing power parity did not hold during economic crises (Hamburger 1929, pp. 748-9). Then, after 1928, Ludwig was concerned by the application of relaxation oscillations to business cycles. His interest in this second topic grew out of a meeting with another Dutch engineer and physicist, Balthazar van der Pol, on May 7, 1928 (Hamburger 1934, p. 112). ${ }^{6}$ That day, Van der Pol gave with his colleague Jan van der Mark a lecture on relaxation oscillations at the Bataafsch Genootschap voor Proefondervindelijke Wijsbegeerte (Batavian Society of

\footnotetext{
${ }^{3}$ In his publications, Hamburger signed "Dr." for Doctor and "Ir." for Engineer ("Ingenieur" in Dutch).

${ }^{4}$ His dissertation is available online: http://resolver.tudelft.nl/uuid:9b9f297d-3bde-42ce-85c9-18e892dedfd6.

${ }^{5}$ See also: https://www.dbnl.org/tekst/lint011tech02_01/lint011tech02_01_0022.php

${ }^{6}$ See Ginoux (2017) on Van der Pol's contribution in relaxation oscillations.
} 
Logic Empirical Philosophy). From 1926, Van der Pol aimed at popularizing his work on relaxation oscillations. Van der Pol and Van der Mark were extremely enthusiastic about the application of this type of oscillation to a multiplicity of phenomena. Van der Pol was indeed totally convinced by the universalism of his concept. In his perspective, relaxation oscillations were not an epiphenomenon, but a new phenomenon with a wide range of applications (Ginoux 2017; Israel 1996; Jovanovic and Le Gall 2021). However, before their meeting at the Batavian Society, neither Van der Pol nor Van der Mark considered a possible application of relaxation oscillations to economic phenomena. Yet they were actively looking for the applications to any new phenomena. It was during this meeting that Hamburger suggested for the first time to apply Van der Pol's relaxation oscillations to economic crises and business cycles (Hamburger 1930a, p. 1; 1931, p. 4). He developed his idea in two articles. The first, "Een Nieuwe Weg Voor Conjunctuur-Onderzoek, Een Nieuwe Richtlijn Voor Conjunctuur-Politiek" ("A New Way for Cyclical Research, a New Guideline for Cyclical Politics"), was published in Dutch in De Economist in 1930.7 The second, "Analogie des fluctuations économiques et des oscillations de relaxation" (Analogy between economic fluctuations and relaxation oscillations), which was an extended translation of the first one, published in French in the journal of the Institut de Statistique de l'Université de Paris in 1931. These two articles have the same structure: in the first part, he describes "the nature of relaxation oscillations" by following Van der Pol's presentation (Van der Pol 1926), ${ }^{8}$ and then he shows that these oscillations can be adapted to the problems of economic crises and business cycles. "Hamburger appears to focus for one part on the "slow-fast" aspect of the concept introduced by Van der Pol allowing him to very accurately describe the evolution of these cycles, and for another part on Van der Pol's model's ability to predict their evolution through a generic equation" (Ginoux 2017, p. 229). As Ginoux (2017, p. 229) pointed out, in order to illustrate his proposition, Hamburger used Van der Pol's example of the Tantalus cup (1930, p. 307) to which he added his own drawing (Figure 1) ${ }^{9}$. Hamburger used the Tantalus cup to provide a mechanical analogy of business cycles.

\footnotetext{
${ }^{7}$ In his 1929 article, he already mentioned the forthcoming publications of his work on this topic (Hamburger 1929).

${ }^{8}$ Ginoux (2017, p. 72) clarified that four versions of this article exist: two Dutch, one German, and one English published the same year. "Although these contributions have the same title and almost the same content, there are differences in each one's conclusion regarding the choice of examples illustrating the relaxation oscillation phenomenon" (Ginoux 2017, p. 72).

${ }^{9}$ The "metaphorical" Tantalus Cup (or vase de Tantale) was first introduced by Le Corbeiller during his presentation at the C.N.A.M., as well as the neon tube example to illustrate the relaxation phenomenon (Ginoux 2017, p. 171).
} 


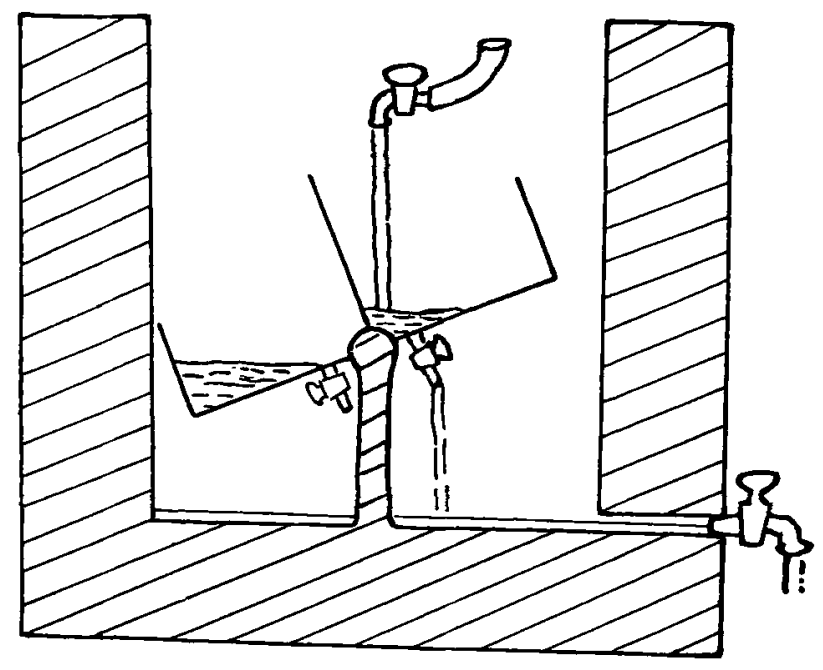

Fig. 1. Hamburger (1930b, p. 16; 1931, p. 15).

Hamburger's attendance at Van der Pol and Van der Mark's lecture was not by chance: Hamburger and van der Pol shared the same circles. Indeed, both were engineers who worked at Philips' Research Laboratories - Van der Pol and Van der Mark joined Philips few years after Hamburger left, and at that time, the Philips' Chemical Laboratory was combined with the 'Natuurkundig Laboratorium' (Physical Laboratory) that was founded in 1914. ${ }^{10}$ Hamburger was also member of the Bataafsch Genootschap voor Proefondervindelijke Wijsbegeerte where Van der Pol and Van der Mark presented their work in 1928. Right after his meeting with Hamburger, Van der Pol added the economic crises to his long list of phenomena represented by relaxation oscillations (Van der Pol and Van der Mark 1928a; b) and that will lead Richard Goodwin to discover this possibility in the 1950s thanks to Le Corbeiller when they were both professors of physics at Harvard University. ${ }^{11}$ Then, during his lectures at the École supérieure d'électricité in Paris on March 10 \& 11, 1930, Van der Pol acknowledged "the very important work of Dr. L. Hamburger" (Van der Pol 1930, pp. 311-2). And he added,

"we have already noted on several occasions that it is a characteristic of relaxation oscillations that their frequency can easily be influenced, but not their amplitude. Dr. Hamburger also found in discussing published statistical work on business cycles that the amplitudes of fluctuations (corrected for their long-run variations) are much more constant than the periods themselves."

${ }^{10}$ There are a few biographical elements regarding Van der Mark in the International Telecommunication Union, vol. 28, (1961) 135 (in English), 159 (in French) or 183 (in Spanish). I thank Jean-Marc Ginoux who sent me a copy.

${ }^{11}$ Goodwin was influenced by Philippe Le Corbeiller who was Van der Pol's assistant when the latter gave his lectures in France. In 1941, during World War II, Le Corbeiller moved to the United States and became professor of physics at Harvard University. At the same period, Goodwing also taught physics in the same university. It was during this period that he met Le Corbeiller in his office and asked him "whether he would teach [him] the theory of nonlinear dynamics. He, then, literally took [him] "by the hand" and taught [him] nonlinear dynamics" (Velupillai 2017, p. fr. 4). See also Goodwin (1951, p. 2), Velupillai (1998) and Venkatachalam and Velupillai (2012).

5 
He concluded: "I believe that the mere conception of business cycles as relaxation oscillations can provide a rational and sufficient basis for an explanation of these important phenomena" (Van der Pol 1930, p. 312). It is worth mentioning that when Van der Pol gave his lectures in Paris, Le Corbeiller was his assistant and helped in their preparation. This information solves Venkatachalam and Velupillai's (2012, p. 62) interrogation about how Le Corbeiller, who helped Goodwin to develop his ideas, may have heard about Hamburger.

Venkatachalam and Velupillai (2012, p. 60) have claimed that Hamburger's work did not really circulate among economists. They have also asserted that the only reference in the mainstream economic literature was by Tinbergen (Tinbergen 1935, pp. 288, fn 71). The reality is different. First of all, in 1932 Hamburger became a member of the Econometric Society. ${ }^{12}$ He participated in the second and the third of its European meetings where he met several academics and could discuss his ideas. Then, it is worth mentioning that Hamburger published his work on business cycles in Dutch and French, which has certainly not helped the dissemination of his ideas among native English speakers. On the contrary, several European authors interested in business cycles referred to Hamburger's ideas. In fact, during the 1930s, Hamburger's work was known by French statisticians and engineers interested in business cycles, in particular Lucien March who invited Hamburger to translate and publish in French his first article on the application of relaxation oscillations. March played a crucial role in the development business cycle analysis in France (Jovanovic and Le Gall 2001; Le Gall 2007). Hamburger's work also circulated among other French academics interested in econometrics, in particular François Divisia who had suggested Frisch in 1926 to create an international association and a journal of econometrics which led to the creation of the Econometric Society (Bjerkholt 2015). His idea also circulated among other pioneer econometricians, like Bernard Chait (1937 [1938]) who developed an original approach for analyzing business cycles ${ }^{13}$. His work was "also discussed among the members of X-crise, a group of alumni and student engineers from the École Polytechnique that sought answers to the deepening crisis. In his account for their monthly periodical of the Paris meeting of the Econometric Society, Divisia placed Hamburger as one of the main contributors to macrodynamic analysis, next to Frisch, Kalecki and Jan Tinbergen" (Assous and Carret 2021, p. 17). In 1929, Hamburger was also invited by the editorial board of Dutch journal De Economist to review and discussed Tinbergen's Ph. D. Thesis. His work was also reviewed in several economic journals like the Journal of the Royal Statistical Society (N. E. C. 1929) or the Zeitschrift für Nationalökonomie / Journal of Economics. In the latter, the reviewer wrote

"The well-known Dutch mathematical statistician and national economist Dr. Hamburger [published two books on the variability of prices]. The two books, which are not easy to read linguistically, offer a number of suggestions, but can only be recommended to readers who are reasonably familiar with the methods of

\footnotetext{
${ }^{12}$ I found the information about his membership in De Ingenieur, 5 Februari 1923, nummer 6. All issues of this journal are available online at the following website: https://www.delpher.nl/.

${ }^{13}$ On Chait's pioneering work in econometrics, see Erreygers and Jolink (2007). Like Hamburger, "his work was not often referred to in the English language literature, perhaps because most of it was written in French" (Erreygers and Jolink 2007, p. 544), although Jan Tinbergen published an obituary in Econometrica, in which he called him "one of the devoted masters of econometrics" (Tinbergen 1958, p. 579).
} 
modern price statistics and the more recent national economic theory" (Tintner 1934, pp. 111-12).

This warning reminds us how innovative Hamburger's ideas were at this time. It is also the reason why Ragnar Frisch paid attention to his work as soon as Hamburger published his first article on business cycles. Specifically, on 6 May 1930, Frisch contacted Hamburger about his paper published in 1930 in De Economist. In his letter, Frisch was extremely enlightening on the potential application of Van der Pol's idea for his research:

I can see that your approach to the economic cycle problem looks very promising. In my own attack on this problem I have also been very definitely under the impression that the conception of rigorous harmonic components must be given up. The way in which I have tried to do so is outlined in my paper "Changing harmonics and other general types of components in empirical series" [published in 1928]. You will see that my approach to the change in the components is purely empirical. In this respect your approach, built on Dr. Van der Pol's idea, is more powerful, it seems to me, since it introduces some rationality into the explanation of the change. I want very much to take this idea up through a closer study and try to combine it with my own idea of a "moving contact approximation." It seems to me that such a combination ought to furnish a very powerful method (Frisch 1930).

Frisch was particularly impressed by the mathematical (i.e. "rational") approach suggested by Hamburger. He asked him to send a copy of his paper (Frisch 1930). Unfortunately, Hamburger did not have more copies, so he answered that "it will be a pleasure for me to send you - who early conceived the necessity of giving up the conception of rigorous harmonic components - a copy of a French paper on this topic which will appear within a few months" (Hamburger 1930b). Hamburger also sent to Frisch the references of his other economic publications.

Frisch probably expected to find a mathematical model that formally applying relaxation oscillations to business cycles; he was disappointed, because Hamburger did not develop such a mathematical model. Indeed, while he provided a mathematical presentation of relaxation oscillations in general, his suggestion to apply such oscillations to business cycles is only qualitative and phenomenological. Frisch expressed this disappointment to Divisia in May 1932 when Divisia mentioned Hamburger's work to Frisch for the first time during the preparations for the second European meeting of the Econometric Society. In his letter, Divisia suggested including a session devoted to business cycles in this conference to be held on 1-4 October 1932, in Paris. When he asked whether he knew Hamburger's work (Divisia 1932), Frisch answered in negative terms:

With regard to Humberger [sic] - I don't think that he will be able to give us anything particularly interesting. You remember, of course, that he wrote a paper some time ago on van der Pol's Theory of Oscillations. That paper itself seemed promising but nothing more seems to have come from him, so on the whole, I am a little bit disappointed with him (Frisch 1932a). 
He consequently persuaded Divisia not to include Hamburger in the program of the second European meeting of the Econometric Society "except as [a paper] to be read by title" (Frisch 1932b)! The title of Hamburger's paper at this conference was on "Some general considerations on an economic system of equilibria" (Anonymous 1933). This correspondence between Frisch and Divisia also helps to clarify why Frisch did not invite Hamburger at the first meeting of the Econometric Society which held on 22-24 September 1931 in Lausanne.

Despite his disappointment with Hamburger's article, Frisch investigated relaxation oscillations seriously subsequent to receiving it. Indeed, Louça (2001, p. 32) pointed out that, in his correspondence with Schumpeter in June 1931, Frisch had already integrated self-maintained oscillations into his analysis. His interest in such oscillations led him to devote the fifth section of his seminal paper, "Propagation problems and impulse problems in dynamic economics" published in 1933 (Frisch 1933), to them. In this section, in which he discussed the economic framework for another "propagation-impulse model" based on Schumpeter's theory of innovations, Frisch explicitly refers to "auto-maintained oscillations," which are the general type of relaxation oscillations (Ginoux and Jovanovic 2021a; b; Jovanovic and Ginoux 2020; Jovanovic and Le Gall 2021). He also provided a mechanical analogy with a pendulum. His description of this analogy is very close to the description of the Tantalus cup, which was introduced by Le Corbeiller for describing relaxation oscillations and used by Hamburger in his two articles devoted to the application of relaxation oscillations to business cycles. However, Frisch does not mention Van der Pol or Hamburger; neither does he mention Le Corbeiller with whom he had discussed the application of relaxation oscillations on several occasions (Ginoux and Jovanovic 2021a). As explained by Ginoux and Jovanovic (2021a), although Le Corbeiller was invited by his friend Divisia at the first conference of the Econometric society, which held on 22-24 September 1931 in Lausanne, Frisch was disappointed in Le Corbeiller's lecture by the lack of mathematical models that formally applied relaxation oscillations to business cycles. ${ }^{14}$ Indeed, Le Corbeiller did not provide any mathematical details during his conference; he referred to the publication of the lectures he gave at the Conservatoire National des Arts et Métiers (CNAM) on 6 and 7 May 1931, a few months before the Lausanne meeting. More important, in the lectures he gave at the CNAM, Le Corbeiller did not mention any application to economics, even if he already knew Hamburger's work (Ginoux and Jovanovic 2021a). Therefore, it was only at the Lausanne meeting that Le Corbeiller added for the first time the possible application of relaxation oscillations to business cycles (remember that it was Divisia who invited Le Corbeiller to this meeting). Moreover, due to his participation at the first meeting of the Econometric Society, Le Corbeiller's article was published in 1933 in the first volume of Econometrica. Hamburger reacted to this publication by submitting a note to Frisch in order to reiterate his earlier work on the subject. This note, published the following year in Econometrica (Hamburger 1934), was his last publication on the possibility of applying relaxation oscillations to business cycles.

\footnotetext{
${ }^{14}$ Divisia and Le Corbeiller, who were friends (Divisia 1931), studied in the École Polytechnique at the same time. It was also Divisia who suggested to invite Le Corbeiller to the second meeting of the Econometric Society (Divisia 1932). Unfortunately, Frisch's letters to Divisia for the month of September 1931 are not in the archives, so it is not possible to know how Frisch reacted to this suggestion.
} 
In 1932, after seven years mainly dedicated to scientific research, Hamburger became consultant advanced engineer in The Hague. His research laboratory enabled him to continue to work in the chemical field both scientifically and practically, but economics was no longer his priority.

In 1939, he moved to the United States with his family just before the Nazi invasion of the Netherlands and changed his name twice. According to the 1940 Census of the United States of America, he lived with his family under the name of Lodewyk Harburry in New York (46 Neptune Ave, New Rochelle, New York) in 1940, then moved to Glens Falls on 1 July 1941, under the name of Lawrence Harbury. When he was in New York, he worked as a research chemist for the Imperial Paper and Color Corporation. ${ }^{15}$ Around 1945, the family moved to Louisville (Kentucky) where he became research Director at the Kentucky Color and Chemical Company in Louisville (Hull 1946, p. 181). He published two articles in chemistry under his new name (Harbury 1946; 1947). He died on 7 January 1968, in California in Menlo Park, San Mateo County. ${ }^{16}$

To conclude: although Ludwig Hamburger was one of the first, if not the first, to suggest applying relaxation oscillations to business cycles, he never developed a mathematical model to support this intuition, nor did he suggest that he planned to do so. However, he provided statistical and phenomenological demonstrations to support it. His interest in economics finally appears as a parenthesis in his engineering career, and his two articles on the possibility of applying relaxation oscillations to business cycles appear as an interesting intuition but not as a research agenda he planned to study. However, his idea directly interested Philippe Le Corbeiller, Ragnar Frisch, and later Richard Goodwin. However, as Ginoux and Jovanovic (2021a) explained, Van der Pol's model is completely independent of the initial conditions, by contrast with business cycle models in general. This is probably one of the reasons why Ragnar Frisch did not follow Hamburger's idea in 1933 and preferred to open a new avenue in the theory of oscillations with forced damped oscillations maintained by erratic shocks (Ginoux and Jovanovic 2021b; Jovanovic and Ginoux 2020).

\section{Hamburger's Bibliography \\ Articles in economics ${ }^{17}$}

Hamburger, L. (1924). "Over de mogelijkheid eener voorspelling van het beloop van prijzen in zoogenaamde onberekenbare tijden" [On the Possibility of Price Forecasting in Normal and in Abnormal Times]. De Ingenieur, 39: 936-943.

\footnotetext{
${ }^{15}$ The Post-Star, Glens Falls, New York, 20 June 1941, page 14, and 13 February 1943, page 5.

${ }^{16}$ The date of his death comes from the California Death Index, 1940-1997. Sacramento, CA, USA: State of California Department of Health Services, Center for Health Statistics.

${ }^{17}$ I did not have access to some of these publications, in particular the articles in the Proceedings of the Netherlands Society for Social Economy and Statistics, consequently I use the titles provided by Hamburger in his correspondence with Frisch.
} 
Hamburger, L. (1925). "Over de mogelijkheid eener voorspelling van het beloop van prijzen in zoogenaamde onberekenbare tijden" [On the Possibility of Price Forecasting in Normal and in Abnormal Times]. De Ingenieur, 40: 367-375.

Hamburger, L. (1928) "Remarks on Trusts, Industrial combinations and the Welfare of the nations". Proceedings of the Netherlands Society for Social Economy and Statistics: $14-28$.

Hamburger, L. (1929) Review of J. Tinbergen's Ph.D. dissertation. Minimumproblemen in de Natuurkunde en de Ekonomie. (Proefschrift Leiden, H. J. Paris, Amsterdam, 1929). De Economist 78: 623-625.

Hamburger, L. (1929) "De veranderlijkheid van prijzen" [The variability of prices]. De Economist 78: 729-754.

Hamburger, L. (1929) "On the possibility of stabilizing the price level". Proceedings of the Netherlands Society for Social Economy and Statistics: 52-68.

Hamburger, L. (1930) "Een nieuwe weg voor conjunctuur-onderzoek, een nieuwe richtlijn voor conjunctuur-politiek" [A new mode of attack in the field of business cyclical research]. De Economist 79: 1-39.

Hamburger, L. (1931) "Analogie des fluctuations économiques et des oscillations de relaxation" [Analogy between economic fluctuations and relaxation oscillations]. Institut de Statistique de l'Université de Paris. Supplément aux Indices $d u$ Mouvement des Affaires, 9 (Janvier): 1-35.

Hamburger, L. (1932) "Remarks on the Agricultural crisis as an element of the general economic depression". Proceedings of the Netherlands Society for Social Economy and Statistics: 113-126.

Hamburger, L. (1933) "Economische grondslagen en richtlijnen vanuit een natuurwetenschappelijk standpunt beschouwd" [Economic foundations and guidelines considered from a scientific point of view]. De Ingenieur 48 (17): 37-60.

Hamburger, L. (1934) "Note on Economic Cycles and Relaxation-Oscillations". Econometrica 2 (1): 112.

Hamburger, L. (1934) "Enkele indices aangaande de technische ontwikkeling langs nieuwe wegen in de voornaamste industrieele landen" [Some indices on technical development along new routes in the main industrial countries]. De Economist 83: 781-808.

Hamburger, L. (1934) "Enkele indices aangaande de technische ontwikkeling langs nieuwe wegen in de voornaamste industrieele landen" [Some indices on technical development along new routes in the main industrial countries]. De Economist 83: 873-894.

\section{Books in economics}

Hamburger, L. (1929). The variability of prices (vol. 1). The Hague.

Hamburger, L. (1929) De veranderlijkheid van prijzen: proeve van economischen "research"-arbeid aangaande variateis in prijs-verhoudingen / Dl. 1 Karakteristieke prijsbetrekkingen in den groothandel van den economisch krachtig land in de twintigste eeuw [The variability of prices: test of economic and "research" work on variability in price ratios / D. 1 Recent International Purchasing Power Disparities in- the Field of Wholesale Pricing]. 's-Gravenhage [The Hague]. 
Hamburger, L. (1929) The Variability of Prices. Second Volume, Part A: Recent International Purchasing Power Disparities in the Field of Wholesale Pricing; The Hague.

\section{ACKNOWLEDGEMENTS}

The author is grateful to Jean-Marc Ginoux, Philippe Le Gall, and Guy Numa, for their helpful remarks, as well as the editor for his constructive advice. I am also grateful to Marianka Louwers, archivist at the Philips Company Archives, who provided me some information about Hamburger.

\section{REFERENCES}

Anonymous. 1933. "Programme de la réunion de la société d'économétrie, paris, octobre, 1932". Econometrica 1, no 1: 110-11.

Assous, M. and V. Carret. 2021. "Relaxation oscillations in the early development of econometrics: Coming (almost) full circle (1929-1951)". In halshs-03206795.

Bjerkholt, O. 2015. "How it all began: The first econometric society meeting, lausanne, september 1931". European Journal of the History of Economic Thought 22, no 6: 114978.

Brugmans, H. and N. Japikse. 1938. Persoonlijkheden in het koninkrijk der nederlanden in woord en beeld. Amsterdam: van Holkema \& Warendorf.

Chait, B. 1937 [1938]. Le mouvement cyclique ou le mouvement non cyclique et l'interdépendance des marchés. Ph. D., Université de Paris.

Divisia, F. 1931. "Letter to ragnar frisch, 20 september 1931". 761A. Oslo: National Library of Norway.

Divisia, F. 1932. "Letter to ragnar frisch, 18 may 1932". 761A. Oslo: National Library of Norway.

Erreygers, G. and A. Jolink. 2007. "Perturbation, networks and business cycles: Bernard chait's pioneering work in econometrics". European Journal of the History of Economic Thought 14, no 3: 543-71.

Frisch, R. 1928. "Changing harmonics and other general types of components in empirical series". Scandinavian Acturial Journal 11: 220-36.

Frisch, R. 1930. "Letter to ludwig hamburger, 6 may 1930". 761B. Oslo: National Library of Norway.

Frisch, R. 1932a. "Letter to françois divisia, 11 june 1932". 761B. Oslo: National Library of Norway.

Frisch, R. 1932b. "Letter to françois divisia, 13 august 1932". 761B. Oslo: National Library of Norway.

Frisch, R. 1933. "Propagation problems and impulse problems in dynamic economics". In Economic essays in honour of gustav cassel, 171-205. London: Allen and Unwin.

Ginoux, J.-M. 2017. History of nonlinear oscillations theory in france (1880-1940): Springer.

Ginoux, J.-M. and F. Jovanovic. 2021a. "Frisch and relaxation oscillations: Why did he never provide a mathematical model". Working paper. 
Ginoux, J.-M. and F. Jovanovic. 2021b. "A mathematical comprehensive analysis of frisch's rocking horse model ". Working paper.

Goodwin, R.M. 1951. "The nonlinear accelerator and the persistence of business cycles". Econometrica 19, no 1: 1-17.

Hamburger, L. 1929. "De veranderlijkheid van prijzen [the variability of prices]". De Economist 78: 729-54.

Hamburger, L. 1930a. "Een nieuwe weg voor conjunctuur-onderzoek, een nieuwe richtlijn voor conjunctuur-politiek". De Economist 79: 1-38.

Hamburger, L. 1930b. "Letter to ragnar frisch, 24 may 1930". 761A. Oslo: National Library of Norway.

Hamburger, L. 1931. "Analogie des fluctuations économiques et des oscillations de relaxation". Indices du Mouvement des Affaires 9 - supplément, no Janvier: 1-35.

Hamburger, L. 1934. "Note on economic cycles and relaxation-oscillations". Econometrica 2, no 1: 112.

Harbury, L. 1946. "Solubility and melting point as functions of particle size. 1.". The Journal Of Physical And Colloid Chemistry 50, no 3: 190-99.

Harbury, L. 1947. "Solubility and melting point as functions of particle size. Ii. The induction period of crystallization". The Journal Of Physical And Colloid Chemistry 51, no 2: 382-91.

Hull, C. 1946. Industrial research laboratories of the united states, including consulting research laboratories - eighth edition. Washington, D.C.: National Research Council National Academy of Sciences.

Israel, G. 1996. La mathématisation du réel. Essai sur la modélisation mathématique. Paris: Le Seuil.

Jovanovic, F. and J.-M. Ginoux. 2020. "The "rocking horse model is rocking": Solving zambelli's puzzle". In https://rlibre.teluq.ca/2084/1/the\%20rocking\%20horse\%20is\%20rocking answer\%20Zambell i_submitted.pdf, ed. Teluq University. Montreal.

Jovanovic, F. and P. Le Gall. 2001. "March to numbers: The statistical style of lucien march". In History of political economy, annuel supplement: The age of economic measurement, eds Klein, JL and Morgan, MS, 86-100.

Jovanovic, F. and P. Le Gall. 2021. "Mathematical analogies: An engine for understanding the transfers between economics and physics". History of Economics Review forthcoming.

Le Corbeiller, P. 1933. "Les systèmes auto-entretenus et les oscillations de relaxation". Econometrica 1, no 3: 328-32.

Le Gall, P. 1994. Histoire de l'econométrie, 1914-1944. L'erosion du déterminisme. Doctoral dissertation, Université Paris I Panthéon-Sorbonne.

Le Gall, P. 2007. A history of econometrics in france. From nature to models. London: Routledge.

Louçã, F. 2001. "Intriguing pendula: Founding metaphors in the analysis of economic fluctuations". Cambridge Journal of Economics 25: 25-55.

N. E. C. 1929. "The variability of prices by lodewijk hamburger - review". Journal of the Royal Statistical Society 92, no 4: 614-16.

Rosser, J.B. 2016. "Economic dynamics". In Handbook on the history of economic analysis volume iii. , eds Faccarello, G and Kurz, HD, 117-32. Cheltenham: Edward Elgar. 
Tinbergen, J. 1935. "Annual survey: Suggestions on a quantitative business cycle theory". Econometrica 3, no 3: 241-308.

Tinbergen, J. 1958. "L'apport de bernard chait à l'econométrie". Econometrica 26, no 4: 579.

Tintner, G. 1934. "Reviewed works: De veranderlijkheid van prijzen. Eerste deel: Karakteristieke prijsbetrekkingen in den groothandel van een economisch krachtig land in de twintigste eeuw by 1 . Hamburger; the variability of prices. Second volume, part a: Recent international purchasing power disparities in the field of wholesale pricing by 1 . Hamburger". Zeitschrift für Nationalökonomie / Journal of Economics 5, no 1: 111-12.

Van Der Pol, B. 1926. "On relaxation-oscillations". The London, Edinburgh, and Dublin Philosophical Magazine and Journal of Science 2, no VII: 978-92.

Van Der Pol, B. 1930. "Oscillations sinusoïdales et de relaxation". l'Onde Electrique 9: 245-56 \& 93-312.

Van Der Pol, B. and J. Van Der Mark. 1928a. "The heartbeat considered as a relaxation oscillation, and an electrical model of the heart". The London Edinburgh and Dublin Philosophical Magazine and Journal of Science 6, no July-December: 763-75.

Van Der Pol, B. and J. Van Der Mark. 1928b. "Le battement du cœur considéré comme oscillation de relaxation et un modèle électrique du cœur". l'Onde Electrique 7: 36592.

Velupillai, K. 1998. "The vintage economist". Journal of economic behavior \& organization 37, no 1: 1-31.

Velupillai, K. 2017. "Richard murphey goodwin (1913-1996)". In The palgrave companion to cambridge economics, ed. Cord, RA. London: Palgrave Macmillan.

Venkatachalam, R. and K. Velupillai. 2012. "Origins and early development of the nonlinear endogenous mathematical theory of the business cycle". Economia Politica 24, no 1: 45-79. 